\title{
The Effects of CuO Nanoparticles on Properties of Self Compacting Concrete with GGBFS as Binder
}

\author{
Ali Nazari*, Mohammad Hossein Rafieipour, Shadi Riahi \\ Department of Materials Science and Engineering, Saveh Branch, \\ Islamic Azad University, Saveh, Iran
}

Received: October 27, 2010; Revised: July 18, 2011

\begin{abstract}
In this work, strength assessments and percentage of water absorption of high performance self compacting concrete containing different amounts of ground granulated blast furnace slag and $\mathrm{CuO}$ nanoparticles as binder have been investigated. Portland cement was replaced by different amounts of ground granulated blast furnace slag and the properties of concrete specimens were investigated. Although it negatively impacts the physical and mechanical properties of concrete at early age of curing, ground granulated blast furnace slag was found to improve the physical and mechanical properties of concrete up to $45 \mathrm{wt}$. (\%) at later ages. $\mathrm{CuO}$ nanoparticles with the average particle size of $15 \mathrm{~nm}$ were partially added to concrete with the optimum content of ground granulated blast furnace slag and physical and mechanical properties of the specimens were measured. $\mathrm{CuO}$ nanoparticle as a partial replacement of cement up to $3.0 \mathrm{wt}$. (\%) could accelerate C-S-H gel formation as a result of increased crystalline $\mathrm{Ca}(\mathrm{OH})_{2}$ amount at the early age of hydration and hence increase strength and improve the resistance to water permeability of concrete specimens. The increased the $\mathrm{CuO}$ nanoparticles' content more than $3.0 \mathrm{wt}$. (\%), causes the reduced the split tensile strength because of the decreased crystalline $\mathrm{Ca}(\mathrm{OH})_{2}$ content required for C-S-H gel formation. Several empirical relationships have been presented to predict flexural and split tensile strength of the specimens by means of the corresponding compressive strength at a certain age of curing. More rapid appearance of the peaks related to hydrated products in X-ray diffraction results, all indicate that $\mathrm{CuO}$ nanoparticles could improve mechanical and physical properties of the concrete specimens.
\end{abstract}

Keywords: concrete, ground granulated blast furnace slag, CuO nanoparticles, compressive strength, split tensile strength, flexural strength, pore structure, XRD, SEM

\section{Introduction}

Self compacting concrete (SCC) is a fluid concrete that spreads through congested reinforcement, fills every corner of the formwork, and consolidated under its weight ${ }^{1}$. SCC necessitates excellent filling ability, good passing ability, and adequate segregation resistance. But it does not include high strength and good durability as significant performance criteria. Virtually all research has used SCC which includes active additions to satisfy the great demand for fines needed for this type of concrete, thereby improving their mechanical properties in comparison with NVC. Köning et al. ${ }^{2}$ and Hauke ${ }^{3}$ registered strength increase in SCCs made with different amount of fly ash. According to Fava et al. ${ }^{4}$, in SCCs with granulated blast furnace slag, this increase is also evident. On the other hand, when limestone filler is used, Fava et al. ${ }^{4}$ and Daoud et al. ${ }^{5}$ achieved a tensile strength in SCC lower than the other normal types of concrete.

Nowadays, most industrial slags are being used without taking full advantages of their characteristics or disposed rather than used. Ground granulated blast furnace (GGBFS) has been used for many years as a supplementary cementitious material in Portland cement concrete, either as a mineral admixture or a component of blended cement $^{6}$. GGBFS typically replaces $35-65 \%$ Portland cement in concrete. Thus a $50 \%$ replacement of each ton of Portland cement would result in a reduction of approximately 500,000 $\mathrm{t}$ of $\mathrm{CO}_{2}$. Using GGBFS as a partial replacement takes advantage of the energy saving in Portland cement is governed by AASHTO M $302^{[7]}$. Three types of GGBFS are typically manufactured. They include Portland cement as covered by AASHTO M85 ${ }^{[8]}$, Portland blast furnace slag cement and slag cement as per AASHTO M240 ${ }^{[9]}$. Utilizing GGBFS as a partial replacement of ordinary Portland cement develops strength and durability of concrete by creating a denser matrix and thereby enhancing the service life of concrete structures. Grinding slag for cement replacement requires only about $25 \%$ energy needed to manufacture Portland cement ${ }^{6}$.

The use of these slags as cementitious components requires only grinding; it will save substantial amounts of energy compared with the production of Portland cement. The partial replacement may decrease the early strength, but increase the later strength and improve microstructure and durability of strengthened Portland cement and concrete considerably ${ }^{10}$. Research results have indicated that clinker less alkali-activated slags show higher strengths, denser structure and better durability than Portland cement under both normal and hydrothermal conditions ${ }^{11-15}$. Thus, the optimum content of these slags is as cementitious material components rather than as aggregates or for base stabilization. Blast furnace slag is a non-metallic material consisting essentially of silicates and aluminosilicates of calcium ${ }^{16}$. It is considerably used in the production of light weight aggregate. When the slag is allowed to cool slowly in the air, it solidifies into gray crystalline material known as crystallized slag. This slag is used as aggregates. When the slag is cooled very rapidly by water, it solidifies and granulates as a granulated slag. The chemical composition of slag can vary over a wide range depending on the nature of the ore, the composition of the limestone flux, coke consumption and the type of iron being made ${ }^{17}$. 
Detwiler et al. ${ }^{18}$ investigated the effectiveness of using supplementary cementing materials to increase the chloride resistance of accelerated cured concrete and they found that concretes containing supplementary cementing materials performed better than the Portland cement concretes. As well, use of supplementary cementing materials can also prevent deleterious expansions related to both delayed ettringite formation ${ }^{19}$ and alkali-silica reaction ${ }^{20}$.

Permeability of concrete is defined as the movement of liquid and/or gas through a mass of concrete under a constant pressure gradient. It is an inherent property of concrete that chiefly depends upon the geometric arrangement and characteristics of the constituent materials. The permeability of concrete is mainly controlled by the solidity and porosity of the hydrated paste present in bulk paste matrix and interfacial transition zone. In the hydrated paste, the capillary and gel pores can be distinguished. The gel pores are very small. Although they constitute a network of open pores, the permeability of this network is very low. Conversely, the capillary pores are relatively large spaces existing between the cement grains. It is the capillary porosity that greatly affects the permeability of concrete $^{21}$. The permeability of SCC is typically lower than that of ordinary concrete. The previous research showed that SCC results in very low water and gas permeability ${ }^{22,23}$. This is mostly attributed to the superior flow properties, dense microstructure and refined pore. Good flow properties result in superb packing condition due to better consolidation, and thus contribute to reduce the permeability of concrete.

Since strength assessments and water permeability of concrete are joined together to affect the final performance of concrete, considering mechanical properties in terms of various types of strengths together with physical properties of concrete specimens seems essential. Hence, in this work, both physical and mechanical properties of concrete specimens have been studied.

There are several works on incorporating nanoparticles into concrete specimens to achieve improved physical and mechanical properties which most of them have focused on using $\mathrm{SiO}_{2}$ nanoparticles ${ }^{24-33}$. In addition, some of the works have conducted on utilizing nano- $\mathrm{Al}_{2} \mathrm{O}_{3}{ }^{[34]}$ and nano- $\mathrm{TiO}_{2}^{[35-37]}$.

$\mathrm{SiO}$, nanoparticles have been found to improve concrete strength $^{25,26,32}$, to increase resistance to water permeability ${ }^{27}$, and to help control the leaching of calcium ${ }^{28}$, which is closely associated with various types of concrete degradation. $\mathrm{SiO}_{2}$ nanoparticles, in addition, have been shown to promote the hydration reactions of $\mathrm{C}_{3} \mathrm{~S}$ as a result of the large and highly reactive surface of the nanoparticles ${ }^{20,29} \cdot \mathrm{SiO}_{2}$ nanoparticles have been found to be more efficient in enhancing strength than silica fume ${ }^{30}$. Adding $10 \% \mathrm{SiO}_{2}$ nanoparticles with dispersing agents has been observed to increase the compressive strength of cementitious composites at 28 days by as much as $26 \%$, compared to only a $10 \%$ increase with adding $15 \%$ silica fume ${ }^{33}$. Even the addition of small amounts of $\mathrm{SiO}_{2}$ nanoparticles has been observed to increase the strength results in improving the 28 day compressive strength by $10 \%$ and flexural strength by $25 \%{ }^{[25]}$. However, these results depend on the production route and conditions of synthesis of $\mathrm{SiO}_{2}$ nanoparticles (e.g., molar ratios of the reagents, the type of reaction media, and duration of the reaction for the sol-gel method) and that dispersion of $\mathrm{SiO}_{2}$ nanoparticles in the paste plays an important role. $\mathrm{SiO}_{2}$ nanoparticles not only behaved as nanofiller to improve the microstructure but also as an activator to accelerate pozzolanic reactions $\mathrm{s}^{30}$.

Incorporating of $\mathrm{TiO}_{2}$ nanoparticles has been addressed in some of the works considering the properties of normal concretes. The flexural fatigue performance of concrete containing $\mathrm{TiO}_{2}$ nanoparticles for pavement has experimentally been studied by Li et al. ${ }^{35}$. They showed that the flexural fatigue performance of concretes containing $\mathrm{TiO}_{2}$ nanoparticles is improved significantly and the sensitivity of their fatigue lives to the change of stress is also increased. In addition, the theoretic fatigue lives of concretes containing $\mathrm{TiO}_{2}$ nanoparticles are enhanced in different extent. With increasing stress level, the enhanced extent of theoretic fatigue number is increased ${ }^{35}$. The abrasion resistance of concrete containing $\mathrm{TiO}_{2}$ nanoparticles for pavement has been experimentally studied ${ }^{36}$. The abrasion resistance of concretes containing $\mathrm{TiO}_{2}$ nanoparticles is significantly improved. The enhanced extent of the abrasion resistance of concrete is decreased by increasing the content of $\mathrm{TiO}_{2}$ nanoparticles ${ }^{36}$. The hydration kinetics of titaniabearing tricalcium silicate phase has been studied ${ }^{37}$. Nano- $\mathrm{TiO}_{2}$-doped tricalcium silicate $\left(\mathrm{C}_{3} \mathrm{~S}\right)$ was obtained by repeated firing of calcium carbonate and quartz in the stoichiometric ratio of $3: 1$ in the presence of varying amounts of titanium dioxide from 0.5 to $6 \%$ of mass. The study revealed that the presence of up to $2 \% \mathrm{TiO}_{2}$ has an inhibiting effect on the rate of hydration of $\mathrm{C}_{3} \mathrm{~S}^{[37]}$.

Previously, the effects of different nanoparticles on physical and mechanical properties of concrete specimens have been studied $^{38-49}$. It has been shown that utilizing nanoparticles in concrete improves the mechanical properties of the specimens besides the improvement in microstructure and pore structure of the concrete specimens. Nanoparticles can act as heterogeneous nuclei for cement pastes, further accelerating cement hydration because of their high reactivity, as nano-reinforcement, and as nano-filler, densifying the microstructure, thereby, leading to a reduced porosity. The most significant issue for all nanoparticles is that of effective dispersion.

Incorporating of other nanoparticles is rarely reported. Therefore, introducing some other nanoparticles which probably could improve the mechanical and physical properties of cementitious composites is inherent.

The aim of this study is investigating the effects of $\mathrm{TiO}_{2}$ nanoparticles on concrete containing "ground granulated blast furnace slag" as binder. Using ground granulated blast furnace slag in concrete specimens as binder has been addressed in several works as mentioned above, but incorporating nanoparticles in the specimens containing ground granulated blast furnace slag to achieve high strength concrete has not been addressed in any work. Although management of waste materials is essential, achieving high strength component by using these materials seems necessary. Thus, combining the management of waste and hazardous materials and nanotechnology can lead to accessing both performance of structural components and reduction of the harmfulness of hazardous materials. The main part of the present study Investigate strength assessments and water permeability of self strength concrete incorporating $\mathrm{CuO}$ nanoparticles which instead of a part of its Portland cement, GGBFS has been used. In addition, pore structure and microstructure of the concrete specimens have been evaluated. Several specimens with a constant amount of polycarboxylate superplasticizer (PC) have been prepared and their physical and mechanical properties have been considered when, instead of cementitious materials, $\mathrm{CuO}$ nanoparticles were partially added to the cement paste.

\section{Materials and Methods}

Ordinary Portland cement (OPC) conforming to ASTM C150[50] standard was used as received. The chemical and physical properties of the cement are shown in Table 1.

$\mathrm{CuO}$ nanoparticles with average particle size of $15 \mathrm{~nm}$ and $45 \mathrm{~m}^{2} \cdot \mathrm{g}^{-1}$ Blaine fineness producing from Suzhou Fuer Import \& Export Trade Co., Ltd was used as received. The properties of $\mathrm{CuO}$ nanoparticles are shown in Table 2.

Crushed limestone aggregates were used to produce self-compacting concretes, with gravel 4/12 and two types of sand: 
Table 1. Properties of Portland cement and GGBFS (wt. (\%)).

\begin{tabular}{llllllllll}
\hline Material & $\mathrm{SiO}_{2}$ & $\mathrm{Al}_{2} \mathrm{O}_{3}$ & $\mathrm{Fe}_{2} \mathrm{O}_{3}$ & $\mathrm{CaO}$ & $\mathrm{MgO}$ & $\mathrm{SO}_{3}$ & $\mathrm{Na}_{2} \mathrm{O}$ & $\begin{array}{c}\mathrm{K}_{2} \mathrm{O} \\
\text { ignition }\end{array}$ \\
\hline Cement & 21.89 & 5.3 & 3.34 & 53.27 & 6.45 & 3.67 & 0.18 & 0.98 & 3.21 \\
GGBFS & 40.3 & 8.12 & 2.11 & 40.12 & 4.23 & 0.56 & 0.13 & 1.21 & 1.96 \\
\hline
\end{tabular}

Specific gravity of cement: $1.7 \mathrm{~g} . \mathrm{cm}^{-3}$

Table 2. The properties of nano-CuO.

\begin{tabular}{cccc}
\hline Diameter $(\mathrm{nm})$ & $\begin{array}{c}\text { Surface volume } \\
\text { ratio }\left(\mathrm{m}^{2} \cdot \mathrm{g}^{-1}\right)\end{array}$ & $\begin{array}{c}\text { Density } \\
\left(\mathrm{g} . \mathrm{cm}^{-3}\right)\end{array}$ & Purity (\%) \\
\hline $15 \pm 4$ & $169 \pm 23$ & $<0.16$ & $>99.9$ \\
\hline
\end{tabular}

one coarse $0 / 4$, for fine aggregates and the other fine $0 / 2$, with a very high fines content (particle size $<0.063 \mathrm{~mm}$ ) of $19.2 \%$, the main function of which was to provide a greater volume of fine materials to improve the stability of the fresh concrete.

Ground granulated blast furnace slag was used as a replacement of Portland cement. The chemical composition of the utilized GGBFS has been illustrated in Table 1 .

A polycarboxylate with a polyethylene condensate defoamed based admixture (Glenium C303 SCC) produced from Muhu (China) Construction Materials Co., Ltd was used. Table 3 shows some of the physical and chemical properties of polycarboxylate admixture used in this study.

Totally, two series of mixtures were prepared in the laboratory trials. C0-GGBFS series mixtures were prepared by cement, fine and ultra-fine crushed limestone aggregates with $19.2 \%$ by weight of ultra-fine ones and 0,15,30, 45 and $60 \%$ by weight of GGBFS replaced by Portland cement. N-GGBFS series were prepared with different contents of $\mathrm{CuO}$ nanoparticles with average particle size of $15 \mathrm{~nm}$. The mixtures were prepared with the cement replacement by $\mathrm{CuO}$ nanoparticles from 1 to $4 \mathrm{wt}$. (\%). To improve workability of the fresh concrete, 1 wt. (\%) of water was replaced by polycarboxylate admixture. The superplasticizer was dissolved in water, and then the nano- $\mathrm{CuO}$ was added and stirred at a high speed for 3 minutes. Though nano- $\mathrm{CuO}$ cannot be dissolved in water, a smaller amount of nano- $\mathrm{CuO}$ can be dispersed evenly by the superplasticizer. The water to binder ratio for all mixtures was set at 0.40 . The binder content of all mixtures was $450 \mathrm{~kg} \cdot \mathrm{m}^{-3}$. The proportions of the mixtures are presented in Table 4.

The mixing sequence for specimens was consisted of homogenizing the sand and cementitious materials for one minute in the mixer and then approximately $75 \%$ of the mixing water were added. The coarse aggregate was introduced and then the superplasticizer was pre-dissolved in the remaining water and was added at the end of the mixing sequence. The total mixing time including homogenizing was 5 minutes.

Several types of tests were carried out on the prepared specimens:

a) Strength evaluation tests: Cubic specimens with $100 \mathrm{~mm}$ edge length for compressive tests. Cylindrical specimens with the diameter of $150 \mathrm{~mm}$ and the height of $300 \mathrm{~mm}$ for split tensile tests and Cubic specimens with $200 \times 50 \times 50 \mathrm{~mm}$ edges length for flexural tests were made. The moulds were covered with polyethylene sheets and moistened for 24 hours. Then the specimens were demoulded and cured in water at a temperature of $20^{\circ} \mathrm{C}$ in the room condition prior to test days. The strength tests of the samples were determined at 7,28 and 90 days of curing. Compressive tests were carried out according to the ASTM C $39^{[51]}$ standard, split tensile tests were done in accordance to the ASTM C $496^{[52]}$ standard and flexural tests
Table 3. Physical and chemical characteristics of the polycarboxylate admixture.

\begin{tabular}{ll}
\hline Appearance & Yellow-brown liquid \\
$\%$ solid residue & Approximately $36 \%$ \\
$\mathrm{pH}$ & $5.2-5.3$ \\
Specific gravity $\left(\mathrm{kg} \cdot \mathrm{L}^{-1}\right)$ & Approximately 1.06 \\
Rotational viscosity $(\mathrm{MPa})$ & 79.30 \\
$\% \mathrm{C}$ & 52.25 \\
$\mathrm{ppm} \mathrm{Na}$ & 9150 \\
$\mathrm{ppm} \mathrm{K}$ & 158 \\
\hline
\end{tabular}

Table 4. Mixture proportion of nano-CuO particles blended concretes.

\begin{tabular}{|c|c|c|c|c|c|}
\hline \multirow[t]{2}{*}{$\begin{array}{c}\text { Sample } \\
\text { designation }\end{array}$} & \multicolumn{2}{|c|}{$\begin{array}{c}\mathrm{CuO} \\
\text { nanoparticles }(\%) \\
\end{array}$} & \multicolumn{3}{|c|}{ Quantities $\left(\mathrm{kg} \cdot \mathrm{m}^{-3}\right)$} \\
\hline & $\begin{array}{l}\text { Weight } \\
\text { percent }\end{array}$ & $\begin{array}{l}\text { Quantity } \\
\left(\text { kg.m }{ }^{-3}\right)\end{array}$ & GGBFS & Cement & $\begin{array}{c}\mathrm{CuO} \\
\text { nanoparticles }\end{array}$ \\
\hline C0-GGBFS0 & 0 & 0 & 0 & 450 & 0 \\
\hline C0-GGBFS15 & 0 & 0 & 67.5 & 450 & 0 \\
\hline C0-GGBFS30 & 0 & 0 & 135 & 450 & 0 \\
\hline C0-GGBFS45 & 0 & 0 & 202.5 & 450 & 0 \\
\hline C0-GGBFS60 & 0 & 0 & 270 & 450 & 0 \\
\hline N1- GGBFS & 1 & 4.5 & 202.5 & 243 & 4.5 \\
\hline N2- GGBFS & 2 & 9.0 & 202.5 & 238.5 & 9.0 \\
\hline N3- GGBFS & 3 & 13.5 & 202.5 & 234 & 13.5 \\
\hline N4- GGBFS & 4 & 18.0 & 202.5 & 239.5 & 18.0 \\
\hline
\end{tabular}

Water to binder [cement + GGBFS + nano-CuO] ratio of 0.40 , fine aggregates $436 \mathrm{~kg} \cdot \mathrm{m}^{-3}$, and coarse aggregate $1023 \mathrm{~kg} \cdot \mathrm{m}^{-3}$.

were performed conforming to the ASTM C $293^{[53]}$ standard. After the specified curing period was over, the concrete cubes were subjected to related test by using universal testing machine. The tests were carried out triplicately and average strength values were obtained;

b) Water permeability tests: Water permeability tests are performed with several methods such as coefficient of water absorption, rate of water absorption and percentage of water absorption. In this work, to evaluate the water permeability of the specimens, percentage of water absorption is an evaluation of the pore volume or porosity of concrete after hardening, which is occupied by water in saturated state. Water absorption values of $\mathrm{CuO}$ nanoparticle blended concrete samples were measured as per ASTM C 642 $2^{[54]}$ after 7, 28 and 90 days of moisture curing;

c) Mercury intrusion porosimetry: There are several methods generally used to measure the pore structure, such as optics method, mercury intrusion porosimetry (MIP), helium flow and gas adsorption ${ }^{55}$. MIP technique is extensively used to characterize the pore structure in porous material as a result of its simplicity, quickness and wide measuring range of pore 
diameter ${ }^{55,56}$. MIP provides information about the connectivity of pores ${ }^{55}$.

In this study, the pore structure of concrete is evaluated by using MIP. To prepare the samples for MIP measurement, the concrete specimens after 90 days of curing were first broken into smaller pieces, and then the cement paste fragments selected from the center of prisms were used to measure pore structure. The samples were immersed in acetone to stop hydration as fast as possible. Before mercury intrusion test, the samples were dried in an oven at about $110^{\circ} \mathrm{C}$ until constant weight to remove moisture in the pores. MIP is based on the assumption that the non-wetting liquid mercury (the contact angle between mercury and solid is greater than $90^{\circ}$ ) will only intrude in the pores of porous material under pressure ${ }^{55,56}$. Each pore size is quantitatively determined from the relationship between the volume of intruded mercury and the applied pressure $^{56}$. The relationship between the pore diameter and applied pressure is generally described by Washburn equation as follows ${ }^{55,56}$ :

$$
D=-4 \gamma \cos \theta / P
$$

where, $\mathrm{D}$ is the pore diameter $(\mathrm{nm}), \gamma$ is the surface tension of mercury (dyne/cm), $\theta$ is the contact angle between mercury and solid $\left(^{\circ}\right)$ and $\mathrm{P}$ is the applied pressure $(\mathrm{MPa})$.

The test apparatus used for pore structure measurement is Auto Pore III mercury porosimeter. Mercury density is 13.5335 g. $\mathrm{mL}^{-1}$. The surface tension of mercury is taken as 485 dynes. $\mathrm{cm}^{-1}$, and the contact angle selected is $130^{\circ}$. The maximum measuring pressure applied is $200 \mathrm{MPa}$ (30000 psi), which means that the smallest pore diameter that can be measured reaches about $6 \mathrm{~nm}$ (on the assumption that all pores have cylindrical shape);

d) Scanning electron microscopy (SEM): SEM investigations were conducted on a Hitachi Model S-9260 CD-SEM apparatus. Backscattered electron (BSE) and secondary electron (SE) imaging was used to study the samples, which were prepared under conditions that ensured their subsequent viability for analytical purposes;

e) X-ray diffraction (XRD): A Philips PW-1730 unit was used for $\mathrm{XRD}$ analysis which was taken from 4 to $70^{\circ}$.

\section{Results and Discussion}

Table 5 shows the compressive strength of C0-GGBFS specimens after 7, 28 and 90 days of curing which are all increased by increasing
GGBFS up to $45 \%$. Using more than $45 \%$ GGBFS has reduced the compressive strength of the specimens and it may be as a result of the reduced $\mathrm{CaO}$ content in GGBFS in comparison with Portland cement. This may be reduce the amount of crystalline $\mathrm{Ca}(\mathrm{OH})_{2}$ and hence C-S-H gel. This fact may be due to various factors, such as using different superplasticizers or greater fines content in the concrete specimens. Roncero and $\mathrm{Gettu}^{57}$ have pointed out the formation of large $\mathrm{CH}$ crystals by using polycarboxylate superplasticizers. These large crystals weaken the aggregate-paste transition zone and hence decrease the compressive strength of concrete by decreasing the aggregate-paste bond. As for the influence of the fines content, the bigger this is the greater the shrinkage becomes ${ }^{58-62}$, giving rise to the appearance of a greater number of micro-cracks in the aggregate paste interface which also reduce the compressive strength. Moreover, by increasing the volume of fines, the specific surface area of the aggregates increases, with the aggregate-paste transition zone is being precisely the weakest phase of the concrete.

Table 5 also shows the compressive strength of N-GGBFS specimens at 7,28 and 90 days of curing. The results show that the compressive strength increases by adding $\mathrm{CuO}$ nanoparticles up to $3.0 \mathrm{wt}$. (\%) replacements (N3-GGBFS series) and then it decreases, although adding $4.0 \mathrm{wt}$. (\%) $\mathrm{CuO}$ nanoparticles produces specimens with much higher compressive strength with respect to C0-GGBFS and N-GGBFS specimens with 1.0 and $2.0 \mathrm{wt}$. (\%) CuO nanoparticles. The reduced compressive strength by adding more than $3.0 \mathrm{wt}$. (\%) $\mathrm{CuO}$ nanoparticles may be due to this fact that the quantity of $\mathrm{CuO}$ nanoparticles presented in the mix is higher than the amount required to combine with the liberated lime during the process of hydration thus leading to excess silica leaching out and causing a deficiency in strength as it replaces part of the cementitious material but does not contribute to strength. Also, it may be due to the defects generated in dispersion of nanoparticles that causes weak zones. The higher compressive strength in the N-GGBFS series mixtures with respect to $\mathrm{C} 0$-GGBFS series may be as a result of the rapid consumption of crystalline $\mathrm{Ca}(\mathrm{OH})_{2}$ which are quickly formed during hydration of Portland cement specially at the early ages as a result of high reactivity of $\mathrm{CuO}$ nanoparticles. As a consequence, the hydration of cement is accelerated and larger volumes of reaction products are formed. Also $\mathrm{CuO}$ nanoparticles recover the particle packing density of the blended cement, directing to a reduced volume of larger pores in the cement paste. However, as indicated, the larger volume of $\mathrm{CuO}$ nanoparticles than $3.0 \mathrm{wt}$. (\%) reduces the compressive strength due to reduction of hydrated lime with respect to the $\mathrm{CuO}$ nanoparticle content in addition to the deficiency occurred during dispersion of $\mathrm{CuO}$ nanoparticles in the cement paste.

Table 5. Strength assessments and water permeability of C0-GGBFS and N-GGBFS specimens.

\begin{tabular}{|c|c|c|c|c|c|c|c|c|c|c|c|c|c|}
\hline \multirow[t]{2}{*}{$\begin{array}{c}\text { Sample } \\
\text { designation }\end{array}$} & \multirow{2}{*}{$\begin{array}{c}\mathrm{CuO} \\
\text { nanoparticles } \\
(\%)\end{array}$} & \multicolumn{3}{|c|}{$\begin{array}{c}\text { Compressive } \\
\text { strength }(\mathrm{MPa})\end{array}$} & \multicolumn{3}{|c|}{$\begin{array}{c}\text { Split tensile } \\
\text { strength }(\mathrm{MPa})\end{array}$} & \multicolumn{3}{|c|}{$\begin{array}{c}\text { Flexural } \\
\text { strength }(\mathrm{MPa})\end{array}$} & \multicolumn{3}{|c|}{$\begin{array}{l}\text { Percentage of water } \\
\text { absorption }(\%)\end{array}$} \\
\hline & & 7 days & 28 days & 90 days & 7 days & 28 days & 90 days & 7 days & 28 days & 90 days & 7 days & 28 days & 90 days \\
\hline C0-GGBFS0 & 0 & 20.6 & 31.6 & 45.5 & 1.2 & 1.6 & 2.1 & 3.7 & 4.2 & 5.6 & 4.28 & 3.89 & 3.21 \\
\hline C0-GGBFS15 & 0 & 18.2 & 35.4 & 49.8 & 1.1 & 1.9 & 2.3 & 3.5 & 4.6 & 6.2 & 4.65 & 3.75 & 3.11 \\
\hline C0-GGBFS30 & 0 & 17.0 & 38.9 & 56.7 & 1.0 & 1.9 & 2.6 & 3.1 & 4.9 & 6.8 & 4.82 & 3.56 & 3.02 \\
\hline C0-GGBFS45 & 0 & 16.0 & 43.7 & 61.2 & 1.0 & 2.1 & 2.9 & 2.8 & 5.4 & 7.3 & 5.02 & 3.41 & 2.89 \\
\hline C0-GGBFS60 & 0 & 15.1 & 40.6 & 58.5 & 0.9 & 2.0 & 2.8 & 2.5 & 5.1 & 7.0 & 5.36 & 3.50 & 2.96 \\
\hline N1- GGBFS & 1 & 22.8 & 53.8 & 68.9 & 1.5 & 2.7 & 3.5 & 3.9 & 5.8 & 7.6 & 3.93 & 1.80 & 1.08 \\
\hline N2- GGBFS & 2 & 25.1 & 59.6 & 72.9 & 1.7 & 3 & 4.2 & 4.3 & 6.3 & 8 & 4.04 & 1.73 & 0.98 \\
\hline N3- GGBFS & 3 & 29.5 & 64.4 & 79.3 & 2 & 3.2 & 4.6 & 4.9 & 7 & 8.6 & 4.13 & 1.59 & 0.84 \\
\hline N4- GGBFS & 4 & 27.3 & 60.5 & 76.5 & 1.8 & 3 & 4.4 & 4.6 & 6.4 & 8.2 & 4.29 & 1.67 & 0.89 \\
\hline
\end{tabular}


Table 5 also shows the split tensile strength and the flexural strength of C0-GGBFS and N-GGBFS series concretes. Similar to the compressive strength, the split tensile strength and the flexural strength of all N-GGBFS specimens is more than those of C0-GGBFS specimens. In addition, the split tensile strength and the flexural strength of N-GGBFS series is increased by adding $\mathrm{CuO}$ nanoparticles up to $3.0 \mathrm{wt}$. (\%) and then it is decreased, similar to the compressive strength results. Since evaluations of strength with different tests are not affordable, here, the relationship between compressive strength and split tensile strength, and the relationship between compressive strength and flexural strength is presented. Figure $1 \mathrm{a}, \mathrm{b}$ and $\mathrm{c}$ show the relationship between the splitting tensile strength and compressive strength of all mixes cured for 7, 28 and 90 days, respectively. In addition, Figure $2 \mathrm{a}, \mathrm{b}$ and $\mathrm{c}$ show the relationship between the flexural strength and compressive strength of all mixes cured for 7, 28 and 90 days, respectively. In all curves, a logarithmic relation has been adopted to show this relationship. The R-squared values are also given in the figures and show a good compatibility between two specified strength. As figures show, at every age of curing, one may predict a specified strength by testing at least one of the specimens' strength.

In addition, Table 5 shows the percentage of water absorption of the specimens. The results indicate that the percentage of water absorption of C0-GGBFS specimens at 7 days of curing is increased

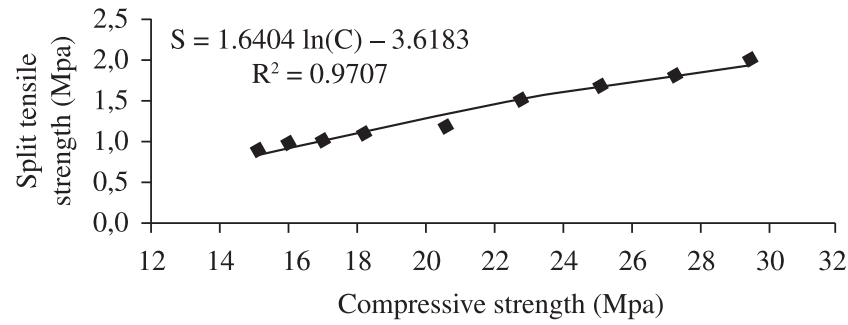

(a)

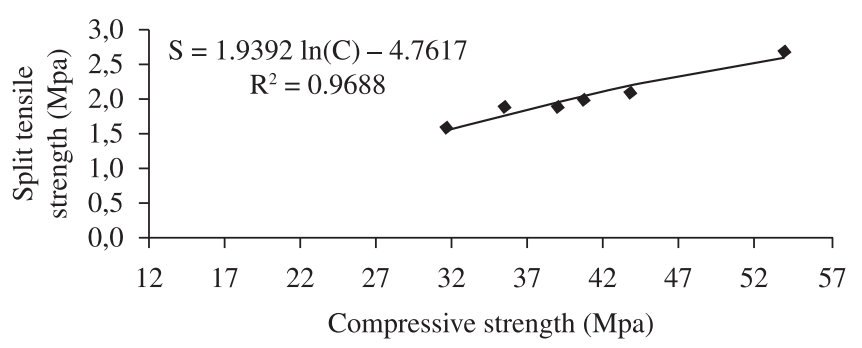

(b)

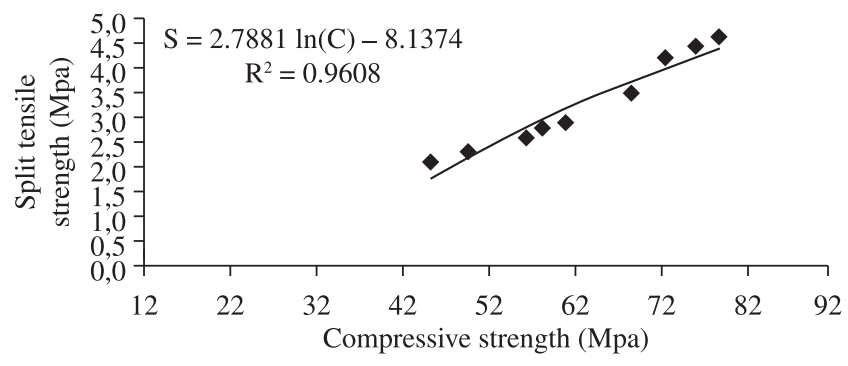

(c)

Figure 1. The relationship between split tensile strength and compressive strength of the specimens cured at a) 7 days, b) 28 days and c) 90 days. $\mathrm{C}$ denotes compressive strength and $\mathrm{S}$ denotes split tensile strength. by increasing GGBFS content while at the later ages (28 and 90 days) it is increased. This behaviour is similar to the specimens' compressive strength in which GGBFS has negative effects at the early age of hydration. As Table 5 shows, the percentage of water absorption in C0-GGBFS specimens at 7 days of is lower than that of N-GGBFS series while at 28 and 90 days of curing, this value is lower for N-GGBFS series concrete. This may be due to more formation of hydrated products in N-GGBFS series at the early ages of curing. As mentioned above, $\mathrm{CuO}$ nanoparticles accelerate formation of cement hydrates and hence the specimens needs more water to produce these products. Therefore, at 7 days of curing, the consumption of water in N-GGBFS series is more than in C0-GGBFS series concrete. At 28 and 90 days of curing, the pore structure of N-GGBFS series concrete is improved and water permeability of these series is decreased with respect to the C0-GGBFS series concrete.

Table 5 also shows that the percentage of water absorption in N-GGBFS series at 28 and 90 ages of curing is decreased by increasing the $\mathrm{CuO}$ nanoparticles content up to $4.0 \mathrm{wt}$. (\%) and then it is increased. Once again, this may be due to unsuitable dispersion of the nanoparticles in the cement paste when the content of the nanoparticles goes beyond $3.0 \mathrm{wt}$. (\%). On the other hand, at 7 days of curing, more water requirement by increasing nanoparticles content up to $3.0 \mathrm{wt}$. $(\%)$ results in the decreased percentage of water absorption. Therefore, it can be suggested that with prolonged curing,

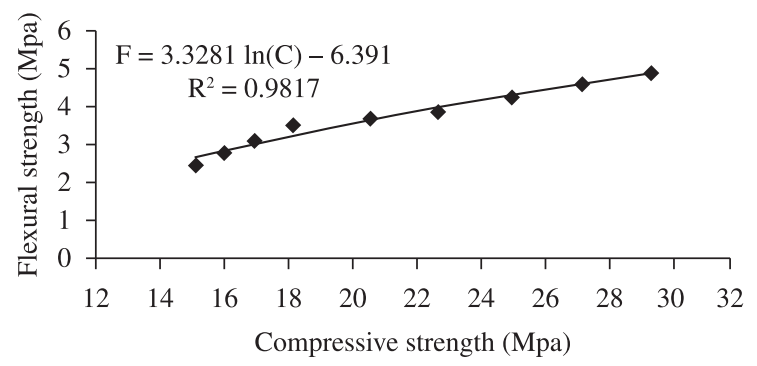

(a)

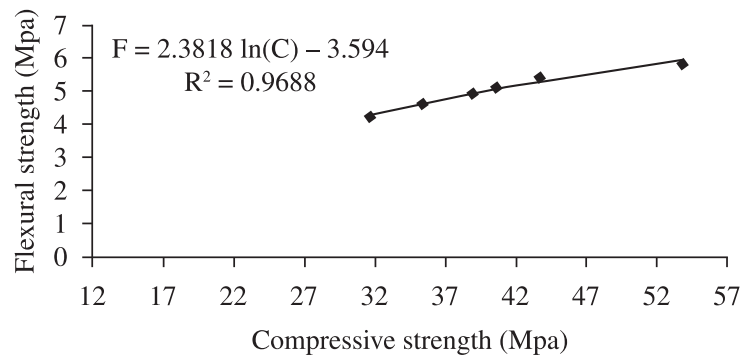

(b)

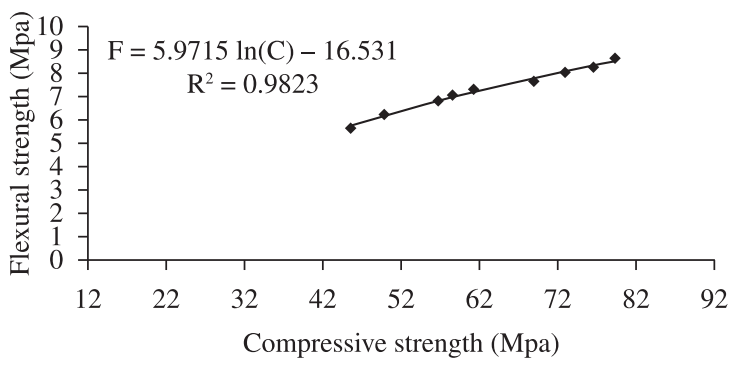

(c)

Figure 2. The relationship between flexural strength and compressive strength of the specimens cured at a) 7 days, b) 28 days and c) 90 days. C denotes compressive strength and $\mathrm{F}$ denotes flexural strength. 
Table 6. Properties of the pores in C0-GGBFS and N-GGBFS specimens.

\begin{tabular}{|c|c|c|c|c|c|c|c|c|c|}
\hline \multirow{2}{*}{$\begin{array}{c}\text { Sample } \\
\text { designation }\end{array}$} & \multirow{2}{*}{$\begin{array}{l}\text { Total specific } \\
\text { pore volume } \\
\quad\left(\mathrm{mL} \cdot \mathrm{g}^{-1}\right)\end{array}$} & \multirow{2}{*}{$\begin{array}{l}\text { Most probable } \\
\text { pore diameter } \\
\quad(\mathrm{nm})\end{array}$} & \multirow{2}{*}{$\begin{array}{c}\text { Prosity } \\
(\%)\end{array}$} & \multirow{2}{*}{$\begin{array}{c}\text { Average } \\
\text { diameter } \\
(\mathrm{nm})\end{array}$} & \multirow{2}{*}{$\begin{array}{l}\text { Median } \\
\text { diameter } \\
\text { (volume) } \\
(\mathrm{nm})\end{array}$} & \multicolumn{4}{|c|}{ Pore size distribution $\left(\mathrm{mL} \cdot \mathrm{g}^{-1}(\%)\right)$} \\
\hline & & & & & & $\begin{array}{c}\text { Pore size } \\
\text { distribution } \\
\left(\mathrm{mL} \cdot \mathrm{g}^{-1}(\%)\right)\end{array}$ & $\begin{array}{c}\text { Few-harm } \\
\text { pores } \\
(20 \sim 50 \mathrm{~nm})\end{array}$ & $\begin{array}{c}\text { Harmful } \\
\text { pores } \\
(50 \sim 200 \mathrm{~nm})\end{array}$ & $\begin{array}{l}\text { Multi-harm } \\
\text { pores } \\
(>200 \mathrm{~nm})\end{array}$ \\
\hline C0-GGBFS0 & 0.0323 & 16 & 9.14 & 11.6 & 25.7 & 0.0044 & 0.0098 & 0.0116 & 0.0041 \\
\hline C0-GGBFS15 & 0.0298 & 13 & 7.01 & 9.8 & 21.3 & 0.0036 & 0.0086 & 0.0095 & 0.0034 \\
\hline C0-GGBFS30 & 0.0284 & 13 & 6.88 & 9.3 & 20.9 & 0.0035 & 0.0084 & 0.0091 & 0.0033 \\
\hline C0-GGBFS45 & 0.0270 & 12 & 6.70 & 8.6 & 19.1 & 0.0030 & 0.0080 & 0.0083 & 0.0030 \\
\hline C0-GGBFS60 & 0.0279 & 13 & 6.76 & 8.9 & 19.6 & 0.0032 & 0.0082 & 0.0086 & 0.0031 \\
\hline N1- GGBFS & 0.0223 & 9.6 & 5.72 & 6.9 & 15.9 & 0.0025 & 0.0067 & 0.0069 & 0.0026 \\
\hline N2- GGBFS & 0.0211 & 8.7 & 5.58 & 6.4 & 15.3 & 0.0023 & 0.0061 & 0.0062 & 0.0023 \\
\hline N3- GGBFS & 0.0201 & 8.7 & 5.49 & 5.7 & 14.6 & 0.0019 & 0.0057 & 0.006 & 0.0021 \\
\hline N4- GGBFS & 0.0207 & 9.6 & 5.53 & 6 & 15 & 0.002 & 0.006 & 0.0061 & 0.0022 \\
\hline
\end{tabular}

increasing the ages and percentages of $\mathrm{CuO}$ nanoparticles can lead to reduction in permeable voids. This is due to the high action and filler effects of $\mathrm{CuO}$ nanoparticles. Another finding is that the interfacial transition zone in concrete is improved due to high reactivity as well as filler effect of the $\mathrm{CuO}$ nanoparticles. This finding is partially in confirmation of the results of the study by Bui et al. ${ }^{63}$.

Table 6 shows that with increasing GGBFS content, the total specific pore volumes of concretes are decreased and the most probable pore diameters of concretes shift to smaller pores and fall in the range of few-harm pore, which indicates that the addition of GGBFS refines the pore structure of concretes. Table 6 also gives the porosities, average diameters and median diameters (volume) of various concretes. The regularity of porosity is similar to that of total specific pore volume. The regularity of average diameter and median diameter (volume) is similar to that of most probable pore diameter. The pore size distribution of concretes is shown in Table 6. It is seen that by increasing GGBFS content, the amounts of pores decrease, which shows that the density of concretes is increased and the pore structure is improved.

Table 6 shows that with increasing $\mathrm{CuO}$ nanoparticles up to $3.0 \mathrm{wt}$. (\%), the total specific pore volumes of concretes are decreased, and the most probable pore diameters of concretes shift to smaller pores and fall in the range of few-harm pore, which indicates that the addition of PC refines the pore structure of concretes.

Table 6 gives the porosities, average diameters and median diameters (volume) of various concretes. The regularity of porosity is similar to that of total specific pore volume. The regularity of average diameter and median diameter (volume) is similar to that of most probable pore diameter.

The pore size distribution of concretes is shown in Table 6. It is observed that by adding nanoparticles, the amounts of is pores decreased, which shows that the density of concretes is increased and the pore structure is improved.

The effectiveness of nano- $\mathrm{CuO}$ in improving the pore structure of concretes increases in the order: N1-GGBFS $<$ N2-GGBFS $<$ N4GGBFS $<$ N3-GGBFS. With increasing the nanoparticles' content, the reduced extent of pores in concretes is all decreased, and the improvement on the pore structure of concretes is weakening.

The mechanism that the nanoparticles improve the pore structure of concrete can be interpreted as follows ${ }^{64}$ : Suppose that nanoparticles are uniformly dispersed in concrete and each particle is contained in a cube pattern, therefore the distance between nanoparticles can be determined. After the hydration begins, hydrate products diffuse and envelop nanoparticles as kernel ${ }^{64}$. If the content of nanoparticles and

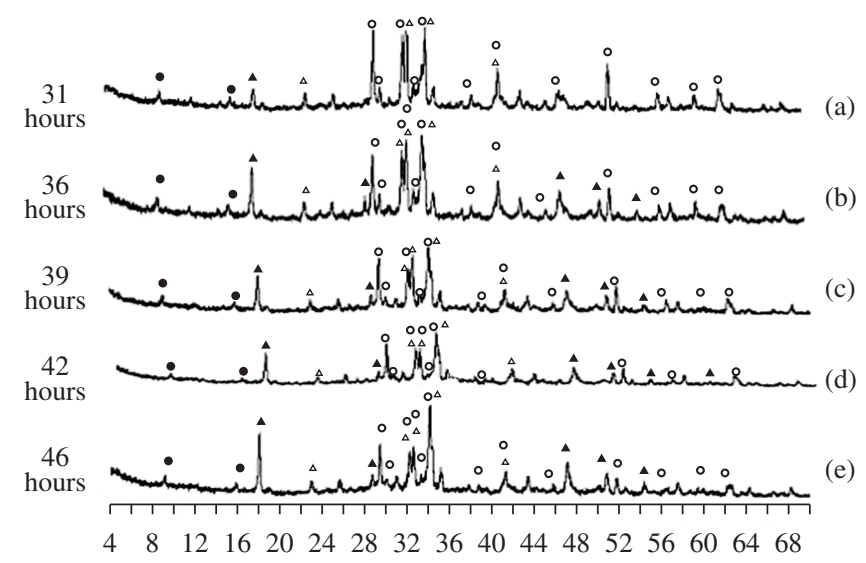

(1)

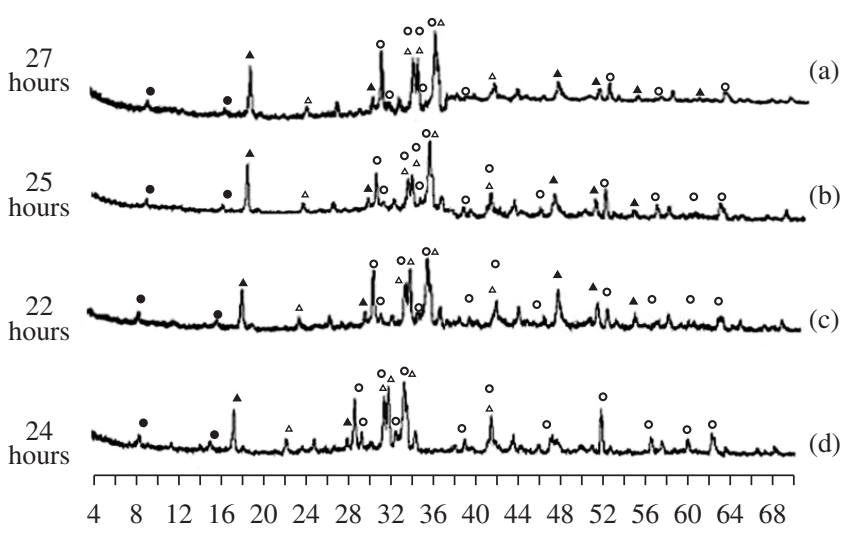

(2)

- $\mathrm{Ca}_{3} \mathrm{SiO}_{5} \Delta \mathrm{Ca}_{2} \mathrm{SiO}_{4} \Delta \mathrm{Ca}(\mathrm{OH})_{2} \quad$ Etringite

Figure 3. XRD results indicating the formation of hydrated products for 1) different C0-GGBFS specimens: a) C0-GGBFS0, b) C0-GGBFS15, c) $\mathrm{C} 0$-GGBFS30, d) $\mathrm{C} 0$-GGBFS45 and e) $\mathrm{C} 0$-GGBFS60; 2) different N-GGBFS specimens: a) N1-GGBFS, b) N2-GGBFS, c) N3-GGBFS and d) N4-GGBFS. 
the distance between them are appropriate, the crystallization will be controlled to be a suitable state through restricting the growth of $\mathrm{Ca}(\mathrm{OH})_{2}$ crystal by nanoparticles. Moreover, the nanoparticles located in cement paste as kernel can further promote cement hydration due to their high activity. This makes the cement matrix more homogeneous and compact. Consequently, the pore structure of concrete is improved evidently such as the concrete containing nano- $\mathrm{CuO}$ in the amount of $1 \%$ by weight of binder ${ }^{64}$.

With increasing the content of $\mathrm{CuO}$ nanoparticles more than $3.0 \mathrm{wt}$. (\%), the improvement on the pore structure of concrete is weakened. This can be attributed to that the distance between nanoparticles decreases with increasing content of nanoparticles, and $\mathrm{Ca}(\mathrm{OH})$, crystal cannot grow up enough due to limited space and the crystal quantity is decreased, which leads to the ratio of crystal to strengthening gel small and the shrinkage and creep of cement matrix increased ${ }^{65}$, thus the pore structure of cement matrix is looser relatively.
On the whole, the addition of nanoparticles improves the pore structure of concrete. On the one hand, nanoparticles can act as a filler to enhance the density of concrete, which leads to the porosity of concrete reduced significantly. On the other hand, nanoparticles can not only act as an activator to accelerate cement hydration due to their high activity, but also act as a kernel in cement paste which makes the size of $\mathrm{Ca}(\mathrm{OH})_{2}$ crystal smaller and the tropism more stochastic.

Figure 3-1 shows XRD analysis of C0-GGBFS specimens at different times after curing. As Figure 3-1 also shows, the peak related to formation of the hydrated products shifts to appear in earlier times indicating the positive impact of $\mathrm{PC}$ on formation of $\mathrm{Ca}(\mathrm{OH})_{2}$ and C-S-H gel.

Figure $4 \mathrm{a}$ and $\mathrm{b}$ show SEM micrographs of C0-GGBFS specimens without and with GGBFS, respectively. The morphological analysis evinced no significant differences in the form and the texture of the different reaction products in pastes with and without admixtures. This may be due to using superplasticizer which helps self compactibility
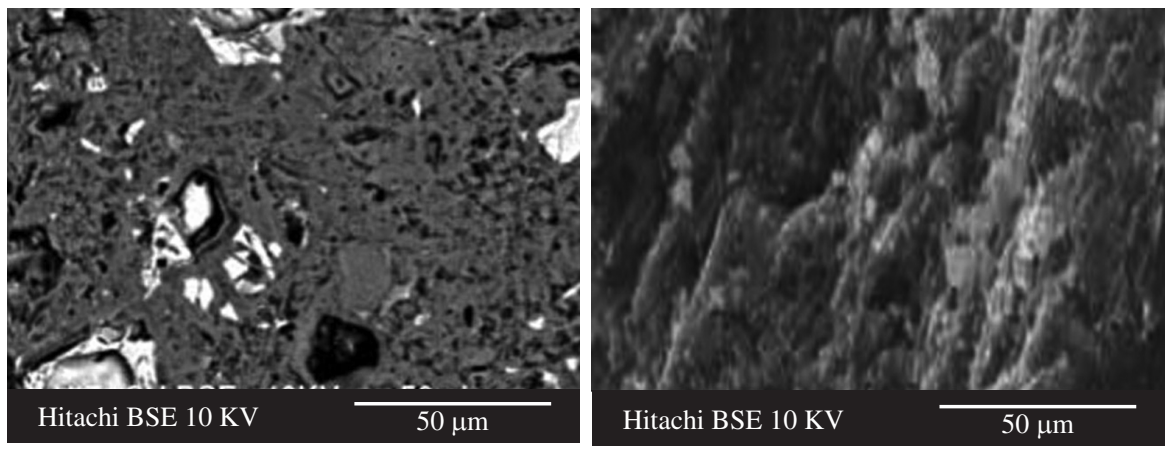

(1)
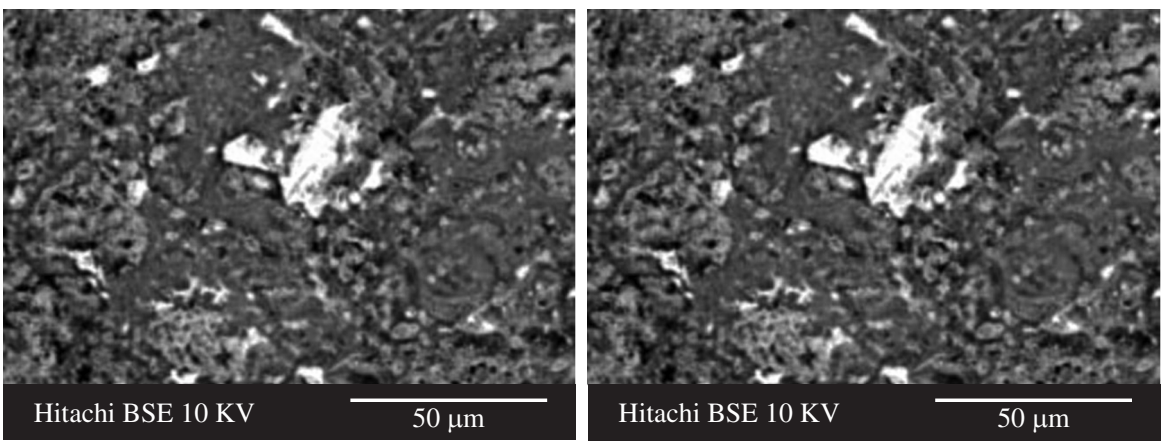

(2)
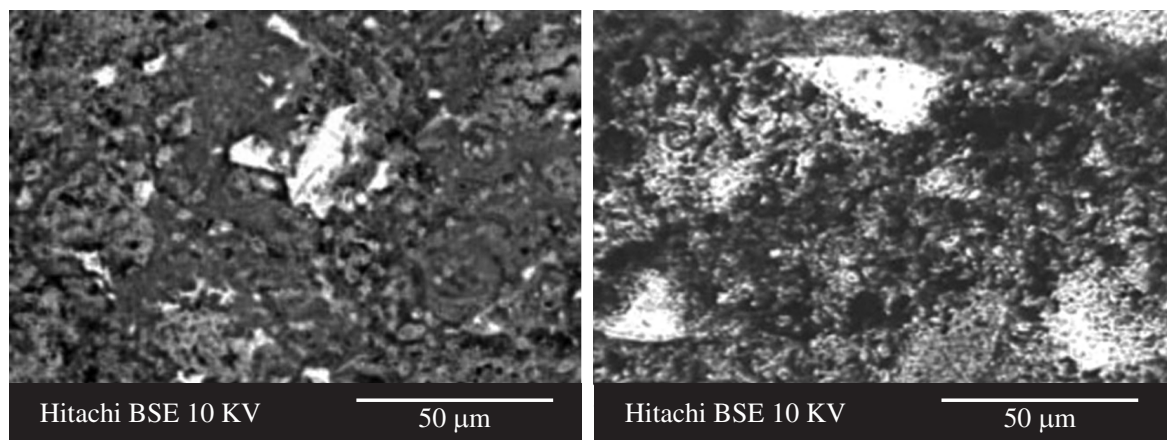

(3)

(b)
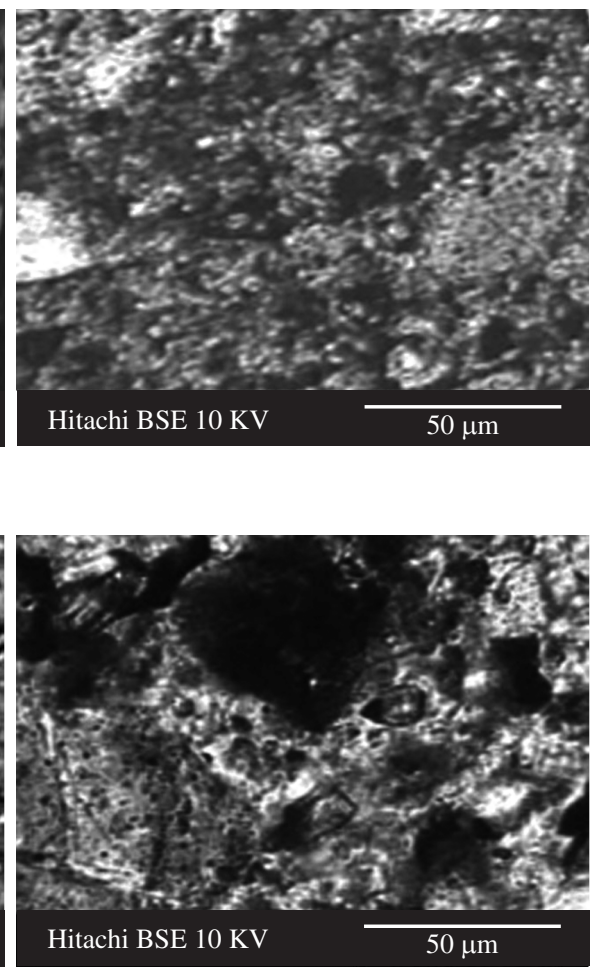

Hitachi BSE $10 \mathrm{KV}$

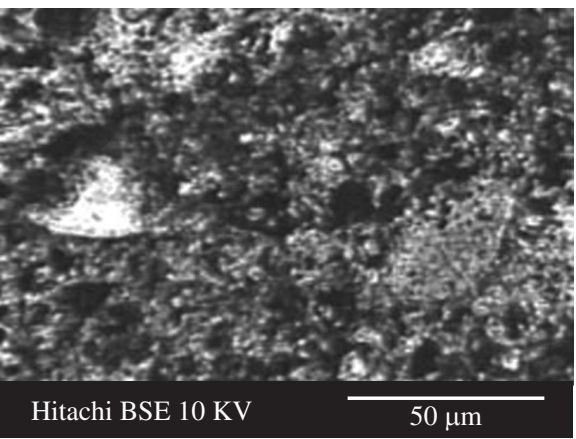

(c)

Figure 4. SEM micrographs of a) C0-GGBFS0 specimen, b) C0-GGBFS45 specimen and c) N3-GGBFS specimens at 7 days (series 1), 28 days (series 2) and 90 days (series 3 ) of curing. 
of the specimens. The beneficial effects of GGBFS in concrete results from the modified microstructure of cementitious paste, which has more capillary pores, filled with low density $\mathrm{C}-\mathrm{S}-\mathrm{H}$ gel than Portland cement paste ${ }^{66-69}$. It can be observed that GGBFS can be effectively used to reduce the pore sizes and cumulative pore volume ${ }^{70}$. It appears that higher GGBFS replacement percentage has denser structure and prevents concrete from water penetration. The GGBFS reacts with water in alkali environment and then with calcium hydroxide to form cement hydration product through pozzolanic reaction to form extra $\mathrm{C}-\mathrm{S}-\mathrm{H}$ gel in the paste and slow down the strength development at early age. Denser microstructure or lower porosity results from higher $\mathrm{C}-\mathrm{S}-\mathrm{H}$ content that represents higher GGBFS replacement percentage and higher durability of concrete.

Portland cement is usually used with GGBFS and the hydration product of $\mathrm{Ca}(\mathrm{OH})_{2}$ activates the slag hydration to from a mixture of low $\mathrm{CaO} / \mathrm{SiO}_{2}(\mathrm{C} / \mathrm{S})$ ratio $\mathrm{CaO}-\mathrm{SiO}_{2}-\mathrm{H}_{2} \mathrm{O}(\mathrm{C}-\mathrm{S}-\mathrm{H})$ and $\mathrm{AF}_{\mathrm{m}}$ (cementitious product from the reaction of reactive alumina and calcium hydroxide) phases. Pozzolanic reaction is also found to increase the $\mathrm{C} / \mathrm{S}$ ratio to a value of about 1.7 in slag-cement blends due to unstable low calcium $\mathrm{C}-\mathrm{S}-\mathrm{H}$ and $\mathrm{Ca}(\mathrm{OH})_{2}$ mixture. When supplementary cementitious material like GGBFS is used in concrete, they do not only reduce the porosity but also the pores become finer and the change in mineralogy of the cement hydrates leads to the reduction in mobility of chloride ions.

Since it has been found that using $45 \%$ GGBFS instead of Portland cement produces a suitable specimen with the optimum properties, $\mathrm{CuO}$ nanoparticles with different amounts of replacement by Portland cement were added to the specimens containing $45 \mathrm{wt}$. (\%) GGBFS and their properties have been investigated in the following section.

Figure 3-2 shows XRD analysis of N-GGBFS specimens at different times after curing. As Figure 3-2 also shows, the peak related to formation of the hydrated products shifts to appear in earlier times indicating the positive impact of $\mathrm{PC}$ on formation of $\mathrm{Ca}(\mathrm{OH})_{2}$ and C-S-H gel at early age of cement hydration.

Finally, Figure 4c show SEM micrographs of N-GGBFS specimens containing 3.0 wt. (\%) of $\mathrm{CuO}$ nanoparticles. Figure $4 \mathrm{c}$ shows a more compact mixture after all days of curing which indicate rapid formation of $\mathrm{C}-\mathrm{S}-\mathrm{H}$ gel in presence of $\mathrm{CuO}$ nanoparticles.

\section{Conclusions}

The results obtained in this study can be summarized as follows:

1) The increased the GGBFS content up to $45.0 \mathrm{wt}$. (\%) results in the increased the split tensile strength. It has been argued that utilizing GGBFS content more than 45.0 wt. (\%) reduces the amount of $\mathrm{CaO}$ which is required for $\mathrm{Ca}(\mathrm{OH})_{2}$ and subsequent C-S-H gel;

2) The pore structure of concrete specimens is found to improve with adding up to $45.0 \mathrm{wt}$. (\%) GGBFS;

3) As the content of $\mathrm{CuO}$ nanoparticles is increased up to 3.0 wt. (\%), the compressive strength, split tensile strength and flexural strength of the specimens is increased. This is due to more formation of hydrated products in presence of $\mathrm{CuO}$ nanoparticles;

4) $\mathrm{CuO}$ nanoparticles could act as nanofillers and improve the resistance to water permeability of concrete at 7 and 28 days and curing. At 7 days of curing, the percentage of water absorption is increased by increasing the nanoparticles content up to $3.0 \mathrm{wt}$. (\%) since the specimens require more water to rapid forming of hydrated products;

5) Some empirical relationships in terms of logarithmic equations were provided to correlate the split tensile strength and flexural strength of a certain mixture to its compressive strength;
6) The pore structure of self compacting concrete containing $\mathrm{CuO}$ nanoparticles is improved and the content of all mesopores and macropores is increased.

\section{References}

1. Khayat KH. Workability, testing, and performance of self-consolidating concrete. ACI Materials Journal. 1999; 96(3):346-353.

2. Köning G, Holsechemacher K, Dehn F and Weie D. Self-compacting concrete-time development of material properties and bond behaviour. In: Ozawa $\mathrm{K}$ and Ouchi M, editors. Proceedings of the 2nd international RILEM symposium on self-compacting concrete. Tokyo: COMS Engineering Corporation; 2001. p. 507-516.

3. Hauke B. Self-compacting concrete for precast concrete products in Germany. In: Ozawa K, Ouchi M editors. Proceedings of the 2nd international RILEM symposium on self-compacting concrete. Tokyo: COMS Engineering Corporation; 2001. p. 633-642.

4. Fava C, Bergol L, Fornasier G, Giangrasso F and Rocco C. Fracture behaviour of self-compacting concrete. In: Wallevik $\mathrm{O}$ and Nielsson I, editors. Proceedings of the 3rd international RILEM symposium on selfcompacting concrete. Reykjavik: RILEM Publications S.A.R.L.; 2003. p. 628-636.

5. Daoud A, Lorrain M, Laborderie C. Anchorage and cracking behaviour of self-compacting concrete. In: Wallevik O and Nielsson I, editors. Proceedings of the 3rd international RILEM symposium on self compacting concrete. Reykjavik: RILEM Publications S.A.R.L.; 2003. p. 692-702.

6. Shi C and Qian J. High performance cementing materials from industrial slags: a review. Resources, Conservation and Recycling. 2000; 29:195-207. http://dx.doi.org/10.1016/S0921-3449(99)00060-9

7. Smith MA. The economic and environmental benefits of increased use of pfa and granulated slag. Resources Policy. 1975; 1(3): 154-170. http://dx.doi.org/10.1016/0301-4207(75)90030-6]

8. Collins RJ and Ciesielski SK. Recycling and Use of Waste Materials and By-Products in Highway Construction. Washington: Transportation Research Board; 1994. National Cooperative Highway Research Program Synthesis of Highway Practice, n. 199.

9. Afrani I and Rogers C. The Effects of Different Cementing Materials and Curing on Concrete Scaling. Cement Concrete and Aggregates. 1994; 16(2):132-139. http://dx.doi.org/10.1520/CCA10291J

10. Malhotra VM. Properties of fresh and hardened concrete incorporating ground granulated blast furnace slag. In: Malhotra VM, editor. Supplementary Cementing Materials for Concrete. Canada: Minister of Supply and Services; 1987. p. 291-336.

11. Isozaki K. Some properties of alkali-activated slag cements. CAJ Revista. 1986; 120-123.

12. Deng Y, Wu X and Tang M. High strength alkali-slag cement. Journal of Nanjing University of Chemical Technology. 1989; 11(2):1-7.

13. Shi C, Wu X and Tang M. Hydration of alkali-slag cements at $150{ }^{\circ} \mathrm{C}$. Cement and Concrete Research. 1991; 21:91-100. http://dx.doi. org/10.1016/0008-8846(91)90035-G

14. Deja J and Malolepszy J. Resistance of alkali-activated slag mortars to chloride solution. In: Proceedings of the Third International Conference on the Use of Fly Ash, Silica Fume, Slag and Natural Pozzolans in Concrete; 1989; Norway, Chicago. Norway: American Concrete Institute; 1989. p. $1547-1561$

15. Shi C, Shen X, Wu X and Tang M. Immobilization of radioactivewastes with Portland and alkali-slag cement pastes. Cemento. 1994; 91(2):97-108.

16. RILEM TC. 73-SBC Committee. Siliceous by-products for use in concrete. Materials and Structures. 1988; 21(1):69-80. http://dx.doi. org/10.1007/BF02472530

17. Sohaib MM, Ahmed SA and Balaha MM. Effect of fire and cooling mode on the properties of slag mortars. Cement and Concrete Research. 2001; 31(11):1533-1538. http://dx.doi.org/10.1016/S0008-8846(01)00561-0

18. Detwiler RJ, Fapohunda CA and Natale J. Use of supplementary cementing materials to increase the resistance to chloride ion penetration of concretes cured at elevated temperatures. ACI Materials Journal. 1994; 91(1):63-66. 
19. Ramlochan T, Zacarias P, Thomas MDA and Hooton RD. The effect of pozzolans and slag on the expansion of mortars cured at elevated temperature: part I expansive behaviour. Cement and Concrete Research. 2003; 33(6):807-814. http://dx.doi.org/10.1016/S0008-8846(02)01066-9

20. Bleszynski RF, Hooton RD, Thomas MDA and Rogers CA. Durability of ternary blend concretes with silica fume and blast furnace slag: laboratory and outdoor exposure site studies. ACI Materials Journal. 2002; 99(5):499-508.

21. Perraton D, Aïtcin P-C and Carles-Gbergues A. Permeability, as seen by the researcher. In: Malier Y, editor. High Performance Concrete: From Material to Structure. London: E \& FN Spon; 1994. p.186-195.

22. Zhu W and Bartos PJM. Permeation properties of self-compacting concrete. Cement and Concrete Research. 2003; 33(6):921-926. http://dx.doi.org/10.1016/S0008-8846(02)01090-6

23. Schutter GD, Audenaert K, Boel V, Vandewalle L, Dupont D, Heirman $\mathrm{G}$ et al. Transport properties in self-compacting concrete and relation with durability: overview of a Belgian research project. In: Wallevik $\mathrm{O}$ and Nielsson I, editors. Self-Compacting Concrete: Proceedings of the Third International RILEM Symposium. Bagneux, France: RILEM Publications; 2003. p. 799-807. RILEM Proceedings, n. 33.

24. Bjornstrom J, Martinelli A, Matic A, Borjesson L and Panas I. Accelerating effects of colloidal nano-silica for beneficial calciumsilicate-hydrate formation in cement. Chemical Physics Letters. 2004; 392(1-3):242-248. http://dx.doi.org/10.1016/j.cplett.2004.05.071

25. Ji T. Preliminary study on the water permeability and microstructure of concrete incorporating nano-SiO2. Cement and Concrete Research. 2005; 35(10):1943-1947. http://dx.doi.org/10.1016/j.cemconres.2005.07.004

26. Li H, Xiao H-g, Yuan J and Ou J. Microstructure of cement mortar with nanoparticles. Composites Part B: Engineering. 2004; 35(2):185-9. http://dx.doi.org/10.1016/S1359-8368(03)00052-0

27. Chong KP and Garboczi EJ. Smart and designer structural material systems. Progress in Structural Engineering and Materials. 2002; 4:417-30. http://dx.doi.org/10.1002/pse.134

28. Gaitero JJ, Campillo I, Guerrero A. Reduction of the calcium leaching rate of cement paste by addition of silica nanoparticles. Cement and Concrete Research. 2008; 38(8-9):1112-1118. http://dx.doi.org/10.1016/j. cemconres.2008.03.021

29. Jennings HM, Bullard JW, Thomas JJ, Andrade JE, Chen JJ and Scherer GW. Characterization and modeling of pores and surfaces in cement paste: correlations to processing and properties. Journal Advanced Concrete Technology. 2008; 6(1):5-29.

30. Scrivener KL and Kirkpatrick RJ. Innovation in use and research on cementitious material. Cement and Concrete Research. 2008; 38(2):128-36. http://dx.doi.org/10.1016/j.cemconres.2007.09.025

31. Lin DF, Lin KL, Chang WC, Luo HL and Cai MQ. Improvements of nano$\mathrm{SiO} 2$ on sludge/fly ash mortar. Waste Management. 2008; 28(6):1081-7. PMid:17512717. http://dx.doi.org/10.1016/j.wasman.2007.03.023

32. Sobolev K, Flores I, Torres-Martinez LM, Valdez PL, Zarazua E, Cuellar EL. Engineering of $\mathrm{SiO} 2$ nanoparticles for optimal performance in nano cementbased materials. In: Bittnar Z, Bartos PJM, Nemecek J, Smilauer V and Zeman J, editors. Nanotechnology in construction: proceedings of the NICOM3 (3th international symposium on nanotechnology in construction). Prague, Czech Republic; 2009. p. 139-48.

33. Qing Y, Zenan Z, Li S and Rongshen C. A comparative study on the pozzolanic activity between nano-SiO2 and silica fume. Journal of Wuhan University of Technology - Materials Science Edition. 2008; 21(3):153-157.

34. Campillo I, Guerrero A, Dolado JS, Porro A, Ibáñez JA and Goñi S. Improvement of initial mechanical strength by nanoalumina in belite cements. Materials Letters. 2007; 61:1889-1892. http://dx.doi. org/10.1016/j.matlet.2006.07.150

35. Li H, Zhang M-h and Ou J-p. Flexural fatigue performance of concrete containing nano-particles for pavement. International Journal of Fatigue. 2007; 29(7):1292-301. http://dx.doi.org/10.1016/j.ijfatigue.2006.10.004
36. Li H, Zhang M-h and Ou J-P. Abrasion resistance of concrete containing nanoparticles for pavement. Wear. 2006; 260(11-12):1262-6. http://dx.doi. org/10.1016/j.wear.2005.08.006

37. Katyal NK, Ahluwalia SC and Parkash R. Effect of TiO2 on the hydration of tricalcium silicate. Cement and Concrete Research. 1999; 29:1851-1855. http://dx.doi.org/10.1016/S0008-8846(99)00171-4

38. Nazari A and Riahi S. Microstructural, thermal, physical and mechanical behavior of the self compacting concrete containing $\mathrm{SiO} 2$ nanoparticles. Materials Science and Engineering: A. 2010; 527:7663-7672. http://dx.doi.org/10.1016/j.msea.2010.08.095

39. Nazari A and Riahi S. The effect of $\mathrm{TiO} 2$ nanoparticles on water permeability and thermal and mechanical properties of high strength self-compacting concrete. Materials Science and Engineering: A. 2010; 528(2):756-763. http://dx.doi.org/10.1016/j.msea.2010.09.074

40. Nazari A. The effects of curing medium on flexural strength and water permeability of concrete incorporating $\mathrm{TiO} 2$ nanoparticles. Materials and Structures. 2010; 44(4):773-786. http://dx.doi.org/10.1617/s11527-0109664-y

41. Nazari A and Riahi S. The effects of zinc dioxide nanoparticles on flexural strength of self-compacting concrete. Composites Part $B$ : Engineering. 2010; 42(2):167-175. http://dx.doi.org/10.1016/j. compositesb.2010.09.001

42. Nazari A and Riahi S. Computer-aided prediction of physical and mechanical properties of high strength cementitious composite containing $\mathrm{Cr}_{2} \mathrm{O}_{3}$ nanoparticles. Nano. 2010; 5(5):301-318. http://dx.doi.org/10.1142/ S1793292010002219

43. Nazari A and Riahi $\mathrm{S}$. The effects of $\mathrm{SiO}_{2}$ nanoparticles on physical and mechanical properties of high strength self compacting concrete. Composites Part B: Engineering. 2011; 42:570-578. http://dx.doi. org/10.1016/j.compositesb.2010.09.025

44. Nazari A and Riahi S. Improvement compressive strength of cementitious composites in different curing media by $\mathrm{Al} 2 \mathrm{O} 3$ nanoparticles. Materials Science and Engineering: A. 2011; 528:1183-1191. http://dx.doi. org/10.1016/j.msea.2010.09.098

45. Nazari A and Riahi S. The effects of $\mathrm{Cr}_{2} \mathrm{O}_{3}$ nanoparticles on strength assessments and water permeability of concrete in different curing media. Materials Science and Engineering: A. 2011; 528:1173-1182. http://dx.doi.org/10.1016/j.msea.2010.09.099

46. Nazari A and Riahi S. $\mathrm{ZrO}_{2}$ nanoparticles effects on split tensile strength of self compacting concrete. Materials Research. 2010; 13(4):485-495.

47. Nazari A and Riahi S. The effects of $\mathrm{ZrO}_{2}$ nanoparticles on physical and mechanical properties of high strength self compacting concrete. Materials Research. 2010; 13(4):551-556.

48. Nazari A and Riahi S. The effects of Zno2 nanoparticles on strength assessments and water permeability of concrete in different curing media. Materials Research. 2011; 14(2):178-188. http://dx.doi.org/10.1590/ S1516-14392011005000030

49. Nazari A and Riahi S. A12O3 nanoparticles in concrete and different curing media. Energy and Buildings. 2011; 43:1480-1488. http://dx.doi. org/10.1016/j.enbuild.2011.02.018

50. American Society for Testing and Materials - ASTM. ASTM C150: Standard Specification for Portland Cement, annual book of ASTM standards. Philadelphia: ASTM; 2001.

51. American Society for Testing and Materials - ASTM. ASTM C39: Standard Test Method for Flexural Strength of Cylindrical Concrete Specimens. Philadelphia: ASTM; 2001.

52. American Society for Testing and Materials - ASTM. ASTM C496: Standard Test Method for Splitting Tensile Strength of Cylindrical Concrete Specimens. Philadelphia: ASTM; 2001.

53. American Society for Testing and Materials - ASTM. ASTM C293: Standard Test Method for Flexural Strength of Concrete (Using Simple Beam With Center-Point Loading). Philadelphia: ASTM; 2001.

54. American Society for Testing and Materials - ASTM. ASTM C642: Standard Test Method for Density, Absorption, and Voids in Hardened Concrete. Philadelphia: ASTM; 2001. 
55. Abell AB, Willis KL and Lange DA. Mercury Intrusion Porosimetry and Image nalysis of Cement-Based Materials. Journal of Colloid and Interface Science. 1999; 211:39-44. http://dx.doi.org/10.1006/ jcis. 1998.5986

56. Tanaka K and Kurumisawa K. Development of technique for observing pores in hardened cement paste. Cement and Concrete Research. 2002; 32:1435-41. http://dx.doi.org/10.1016/S0008-8846(02)00806-2

57. Roncero J and Gettu R. Influencia de los superplastificantes en la microestructura de la pasta hidratada y en el comportamiento diferido de los morteros de cemento. Cemento Hormigón. 2002; 832:12-28.

58. Hans-Ërik G and Pentti P. Properties of SCC-especially early age and long term shrinkage and salt frost resistance. In: Skarendahl Å and Petersson Ö, editors. Proceedings of the 1st international RILEM symposium on self-compacting concrete. Stockholm: RILEM Publications S.A.R.L.; 1999. p. 211-225.

59. Song HW, Byun KJ, Kim SH and Choi DH. Early-age creep and shrinkage in self-compacting concrete incorporating GGBFS. In: Ozawa $\mathrm{K}$ and Ouchi M, editors. Proceedings of the 2nd international RILEM symposium on self-compacting concrete. Tokyo: COMS Engineering Corporation; 2001. p. 413-422.

60. Hammer TA, Johansen $\mathrm{K}$ and Bjøntegaard Ø. Volume changes as driving forces to self-induced cracking of norwegian SCC. In: Ozawa K and Ouchi $\mathrm{M}$, editors. Proceedings of the 2 nd international RILEM symposium on self-compacting concrete. Tokyo: COMS Engineering Corporation; 2001. p. $423-432$.

61. Turcry P and Loukili A. A study of plastic shrinkage of self -compacting concrete. In: Wallevik O and Nielsson I, editors. Proceedings of the 3rd international RILEM symposium on self-compacting concrete. Reykjavik: RILEM Publications S.A.R.L.; 2003. p. 576-585.

62. Heirman $G$ and Vandewalle $L$. The influence of fillers on the properties of self-compacting concrete in fresh and hardened state. In: Wallevik $\mathrm{O}$ and Nielsson I, editors. Proceedings of the 3rd international RILEM symposium on self-compacting concrete. Reykjavik: RILEM Publications S.A.R.L.; 2003. p. 606-618.

63. Bui DD, Hu J and Stroeven P. Particle size effect on the strength of rice husk ash blended gap-graded Portland cement concrete. Cement and Concrete Composites. 2005; 27(3): 357-366. http://dx.doi.org/10.1016/j. cemconcomp.2004.05.002

64. Puertas F, Santos H, Palacios M and Martínez-Ramírez S. Polycarboxylate superplasticiser admixtures: effect on hydration, microstructure and rheological behaviour. Advances in Cement Research. 2005;17(2):77-89. http://dx.doi.org/10.1680/adcr.2005.17.2.77

65. Jawed J, Skalny J and Young JF. Hydration of Portland Cement. In: Barnes P, editor. Structure and Performance of Cements. Essex: Applied Science Publishers; 1983. p. 284-285.

66. Ye G, Xiu X, De Schutter G, Poppe AM and Taerwe L. Influence of limestone powder as filler in SCC on hydration and microstructure of cement pastes. Cement and Concrete Composites. 2007;29(2):94-102. http://dx.doi.org/10.1016/j.cemconcomp.2006.09.003

67. Arya $\mathrm{C}$ and $\mathrm{Xu}$ Y. Effect of cement type on chloride binding and corrosion of steel in concrete. Cement and Concrete Research. 1995; 25(4):893-902. http://dx.doi.org/10.1016/0008-8846(95)00080-V

68. Polder RB and Rooij D. Durability of marine concrete structures-field investigations and modeling. Heron. 2005; 50(3):133.

69. Glass GK, Reddy B and Buenfeld NR. Corrosion inhibition in concrete arising from its acid neutralization capacity. Corrosion Science. 2000; 42:1587-1598. http://dx.doi.org/10.1016/S0010-938X(00)00008-1

70. Basheer PAM, Gilleece PRV, Long AE and McCarter WJ. Monitoring electrical resistance of concretes containing alternative cementitious materials to assess their resistance to chloride penetration. Cement and Concrete Composites. 2002; 24:437. http://dx.doi.org/10.1016/S09589465(01)00075-0 